\title{
Pengadaan Gamelan yang Akuntabel dengan Metode Tender Dikecualikan di Dinas Kebudayaandaerah Istimewa Yogyakarta
}

\author{
Sumitro Yuwono ${ }^{1}$, Tri Nugroho ${ }^{2}$ \\ ${ }^{1}$ Pengelola Barang Milik Negara pada Dinas Pendidikan, Pemuda dan Olahraga DIY \\ ${ }^{2}$ Prodi Magister Ilmu Pemerintahan, STPMD “APMD” Yogyakarta DIY \\ ${ }^{1}$ Korespondensi Penulis: yuwonosumitro@gmail.com
}

\begin{abstract}
Abstrak: Artikel ini bertujuan menjawab masalah: Bagaimana pengadaan gamelan dengan metode tender yang dikecualikan di Kundha Kabudayan DIY dan apa kendala yang dihadapi? Hasil penelitian ini: Pengadaan gamelan dengan metode tender yang dikecualikan di Kundha Kabudayan DIY sudah dilaksanakan secara akuntabel. Alasannya, pengadaan gamelan dengan metode tender yang dikecualikan ini: a. telah dilakukan secara transparan di semua tahapannya; b. telah dilaksanakan berdasarkan perpres dan peraturan yang berlaku; c. dikendalikan dengan SOP berdasarkan Perpres dan peraturan yang berlaku; d. Para Tenaga Teknis dan Pokja BLP dijamin kompetensinya; e. merupakan respon atas animo masyarakat luas. Kendala-kendala yang dihadapi adalah a. belum adanya standar penentuan tenaga ahli dalam Tim Teknis; b. kesulitan memacu pengrajin untuk menyelesaikan sesuai target waktu; dan c. kekurangan pengrajin gamelan perunggu di wilayah DIY.
\end{abstract}

Kata-kata Kunci: Pengadaan Gamelan, Tender yang Dikecualikan

\begin{abstract}
This article aims to answer the problem: How is the procurement of gamelan except for the tender method in Cultural Office (Kundha Kabudayan) of Yogyakarta Special Region and what are the barriers faced? Research findings are as follows: the procurement of gamelan except for the tender method in Cultural Office of Yogyakarta Special Region has been carried out in an accountable manner. The reasons are the procurement of gamelan using the excluded tender method: a). has been carried out transparently at all stages; $b$ ). has been carried out based on the Presidential Regulation and applicable regulations, and the results are better; c). controlled by Standard Operating Procedure (SOP); d). The technical personnel and the Procurement Service Working Group are guaranteed competence; $e$ ). is a response to the interest of the wider community. The barriers faced are a). the absence of a standard for determining experts in the Technical Team; b). difficulty spurring craftsmen to complete according to the target time; and c). the shortage of bronze gamelan craftsmen in the Yogyakarta area.
\end{abstract}

Keywords: Gamelan Procurement, Exempted Tender

Article History:

Received : 2021-07-01

Revised : 2021-07-28

Accepted : 2021-08-25

\section{PENDAHULUAN}

Budaya Pemerintahan Daerah Istimewa Yogyakarta yang disebut SATRIYA (Peraturan Gubernur Nomor 72 Tahun 2008) dipilih untuk mewujudkan visi DIY yaitu peningkatan kemuliaan martabat manusia Jogja dan misinya, antara lain, mewujudkan peningkatan kualitas hidup - kehidupan - penghidupan masyarakat yang berkeadilan dan berkeadaban. Penyampaian visi Pemda DIY ini dikemas dengan Dialog Budaya dan Gelar Seni "Yogya Semesta". Pada kesempatan itu, visi dan misi Pemda DIY disampaikan oleh Ki Dalang Catur "Benyek" Kuncoro, S.Sn. dengan pagelaran wayang kulit ringkes "Gelaring Ratnakara Sarana Gumregahing Nagari Ngayogyakarta" (https://jogjaprov.go.id/, diunduh tanggal 28 Oktober 2020).

Pagelaran wayang kulit tidak hanya diselenggarakan oleh Pemerintah Daerah, namun juga oleh masyarakat luas, di berbagai kesempatan, seperti: perkawinan, sunatan, syukuran atas keberhasilan pembangunan, merti bumi, dll. Kenyataan tersebut memperlihatkan bahwa budaya dan gamelan sangat dekat dan lekat dengan kehidupan pemerintah dan masyarakat, serta menjadi ciri khas masyarakat Jawa (termasuk Yogyakarta). Gamelan merupakan bagian 
yang tak terpisahkan dari kehidupan masyarakat Jawa. Gamelan bukan sekadar alat musik, namun di dalamnya juga terdapat spirit dan filosofi hidup yang begitu adiluhung (AhmadIbo, Gamelan, Kesenian Adiluhung dari Jawa, https://www.indonesiakaya.com, diunduh tanggal 26 Oktober 2020).

Menyadari akan kekhasan dan peran penting gamelan ini, pemerintah Daerah DIY melalui Biro Pengembangan Infrastruktur Wilayah dan Pembiayaan Pembangunan, Bagian Layanan Pengadaan Barang/Jasa, dan Kundha Kabudayan dalam beberapa tahun terakhir melakukan pengadaan gamelan untuk sekolah-sekolah, sanggar-sanggar seni, desa-desa Budaya, untuk masyarakat Jawa Bengkulu dan untuk luar negeri: KJRI New York, KBRI Finlandia, KBRI Belgia, dengan tujuan memperkenalkan dan melestarikan budaya Jawa, termasuk Yogyakarta. Dana pengadaan Gamelan tersebut berasal dari Dana Keistimewaan, yang diperoleh DIY setelah DIY ditetapkan sebagai Daerah Istimewa, berdasarkan Undang-undang Nomor 13 Tahun 2012 tentang Keistimewaan DIY.

Pada awalnya, pengadaan gamelan dilakukan dengan metode tender biasa (terbuka), karena paket pengadaan gamelan umumnya melebihi Rp. 200.000.000,-. Berbagai tahapan dilakukan sesuai peraturan yang berlaku. Namun di lapangan, semua hal yang legal tersebut ternyata menyimpan berbagai masalah. Masalah itu antara lain: cara tender biasa ini tak terjangkau oleh para pengrajin gamelan yang berkualitas karena mereka tidak memiliki surat resmi sebagai penyedia jasa (CV) yang legal. Para pengrajin ini umumnya kemudian dipayungi oleh para penyedia jasa yang legal, namun penyedia jasa tersebut tidak memiliki pengetahuan yang mencukupi tentang gamelan. Akibatnya, pemerintah daerah menderita kerugian ganda: di satu sisi pemerintah daerah harus mengeluarkan dana ekstra untuk penyedia jasa, yang berperan sebagai "perantara" dan di sisi lain tidak mendapatkan barang (gamelan) sesuai dengan kualitas yang diinginkan, karena lemahnya control kualitas dari pihak "perantara". Fakta inilah yang di kemudian hari menimbulkan masalah berkepanjangan, karena fakta tersebut menjadi temuan-temuan sebagai kerugian Negara. Contoh dari kasus ini adalah kasus yang terjadi pada Tahun 2013 di Dinas Pendidikan, Pemuda dan Olah Raga, dengan kerugian Negara 1,2 Milliar.

Terbitnya Peraturan Presiden Nomor 18 Tahun 2018 tentang Pengadaan Barang/Jasa Pemerintah dan Peraturan Lembaga Kebijakan Pengadaan Barang/Jasa Pemerintah (LKPP) Nomor 12 Tahun 2018 telah membawa angin segar dalam pengadaan barang oleh pemerintah, karena untuk pertama kalinya memuat dan mengatur "Pengadaan barang/Jasa yang dikecualikan pada pengadaan barang/jasa Pemerintah". Disebutkan dalam Peraturan LKPP Nomor 12 Tahun 2018 bahwa salah satu yang dikecualikan adalah "pengadaan barang/jasa yang dilaksanakan sesuai dengan praktik bisnis yang sudah mapan” (Pasal 7), yang meliputi, antara lain: Barang/jasa yang merupakan karya seni dan budaya dan/atau industri kreatif (Lampiran I Peraturan LKPP). Dengan demikian, gamelan, yang merupakan karya seni dan budaya, pengadaannya dapat dilakukan dengan metode "yang dikecualikan" ini.

Mulai Tahun 2018, Bagian Layanan Pengadaan Barang/Jasa dari Biro Pengembangan Infrastruktur Wilayah dan Pembiayaan Pembangunan, dan Kundha Kabudayan melaksanakan pengadaan gamelan dengan metode tender yang dikecualikan. Hasilnya, dengan metode ini pengadaan gamelan mempunyai nilai efisiensi yang lebih tinggi. Benarkah demikian? Benarkah pengadaan gamelan dengan metode tender yang dikecualikan itu akuntabel? Benarkah hasilnya lebih berkualitas dan lebih efisien? Pertanyaan-pertanyaan awal ini lah, yang mendorong peneliti untuk menulis artikel ilmiah berdasarkan penelitian dengan judul: "Pengadaan Gamelan dengan Metode Tender "yang Dikecualikan" di Kundha Kabudayan, Daerah Istimewa Yogyakarta.

Peneliti menyadari bahwa ada peneliti lain yang telah melakukan penelitian tentang akuntabilitas pengadaan barang, antara lain: 
1. Yanuar Siswo Nugroho dan Zulkifli, yang meneliti pada Tahun 2019, dengan judul: "Akuntabilitas Publik Pengadaan Barang/Jasa Pemerintah Secara Elektronik (EProcurement) di Pemerintah Daerah Daerah Istimewa Yogyakarta", dari Magister Manajemen STIE Widya Wiwaha, Yogyakarta. (Jurnal Riset Manajemen, Vol. 6, No. 2, Hal. 173-184, Juli 2019).

2. Badzlina Daroyani Novitaningrum, pada Tahun 2014, dengan judul penelitian: "Akuntabilitas dan Transparansi Pengadaan Barang dan Jasa Pemerintah Melalui Electronic Procurement (Best Practice di Pemerintah Kota Surabaya)", dari Program Studi Ilmu Administrasi Negara, FISIP, Universitas Airlangga, Surabaya (Jurnal Kebijakan dan Manajemen Publik, Volume 2, Nomor 1, Januari 2014).

3. Qori Lusi Pratiwi, Choirul Saleh, Abdul Wahid, Tahun 2014, dengan judul penelitian: "Akuntabilitas dalam Pengadaan Barang dan Jasa Pemerintah Melalui Sistem EProcurement (Studi Pada Layanan Pengadaan Secara Elektronik Pemerintah Kabupaten Kediri), Jurusan Administrasi Publik. Fakultas Ilmu Administrasi, Universitas Brawijaya, Malang (Jurnal Adiministrasi Publik (JAP), Vol. 2, No. 2, Hal. 344-349, 2014).

Jika artikel ilmiah yang berbasis penelitian ini dibandingkan dengan ketiga penelitian terdahulu, maka terdapat kesamaan dan perbedaan:

Kesamaannya: a. Semua penelitian ini meneliti tentang akuntabilitas pengadaan barang; b. Semua pengadaan barang secara Elektronik (melalui system E-Procurement); c. Semua penelitian menggunakan metode penelitian deskriptif-kualitatif.

Perbedaannya: a. Ketiga penelitian terdahulu meneliti tentang pengadaan barang dengan metode tender terbuka, sedangkan penelitian ini menggunakan metode tender yang dikecualikan; b. Ketiga penelitian lain meneliti tentang pengadaan barang pada umumnya sesuai perundang-undangan yang berlaku, sedangkan penelitian ini memfokuskan diri barang khusus, yaitu Gamelan; c. Ketiga penelitian terdahulu merupakan penelitian yang dilakukan di Pemerintah Daerah (provinsi, Kabupaten dan Kota) sedangkan penelitian ini dilakukan di Kundha Kabudayan (Daerah Istimewa Yogyakarta)

Berdasarkan uraian tersebut, artikel ini memfokuskan diri pada: 1. Lima dimensi akuntabilitas dalam pengadaan gamelan dengan metode tender yang dikecualikan di Kundha Kabudayan Daerah Istimewa Yogyakarta yaitu: Dimensi Transparansi, Pertanggungjawaban, Pengendalian, Tanggung jawab, Responsivitas; dan 2. Kendala-kendala yang dihadapi dalam pengadaan gamelan tersebut.

Rumusan masalah dari artikel ini: 1. Bagaimana pengadaan Gamelan dengan metode tender yang dikecualikan di Kundha Kabudayan Daerah Istimewa Yogyakarta? dan 2. Apa saja kendala yang dihadapi dalam pengadaan gamelan tersebut? Sedangkan tujuan artikel ini ialah: 1. Mendeskripsikan pengadaan Gamelan dengan metode tender yang dikecualikan di Kundha Kabudayan Daerah Istimewa Yogyakarta; 2. Mengetahui kendala-kendala yang dihadapi dalam pengadaan gamelan itu.

\section{METODE PENELITIAN}

Metode penelitian yang digunakan: deskriptif-kualitatif, dengan obyek penelitian Pengadaan Gamelan dengan Metode Tender yang Dikecualikan di Kundha Kabudayan Daerah Istimewa Yogyakarta. Teknik pemilihan informan yang digunakan adalah teknik purposive, dengan 8 informan. Teknik pengumpulan data: Observasi, Wawancara, Dokumentasi. Teknik analisis data: teknik analisis interaktif yang meliputi: reduksi data, penyajian data dan penarikan kesimpulan. 


\section{HASIL DAN PEMBAHASAN}

\section{Pengadaan Gamelan Dengan Metode Tender yang Dikecualikan di Kundha Kabudayan DIY}

Pengadaan gamelan yang dilakukan oleh pemerintah daerah DIY merupakan bagian dari pelayanan publik pemerintah. Pelayanan publik dimengerti sebagai kegiatan atau rangkaian kegiatan dalam rangka pemenuhan kebutuhan pelayanan sesuai dengan peraturan perundangundangan bagi setiap warga negara dan penduduk atas barang, jasa, dan atau pelayanan administratif yang disediakan oleh penyelenggara pelayanan publik (Undang-undang Nomor 25 Tahun 2009 tentang Pelayanan Publik pasal 1 ayat 1)

Asas Pelayanan Publik dalam Kepmenpan Nomor 63 Tahun 2003 dijelaskan sebagai berikut: 1). Transparansi, artinya bersifat terbuka, mudah dan dapat diakses oleh semua pihak yang membutuhkan dan disediakan secara memadai serta mudah dimengerti; 2). Akuntabilitas, artinya dapat dipertanggungjawabkan sesuai dengan ketentuan peraturan perundang-undangan; 3). Kondisional, artinya sesuai dengan kondisi dan kemampuan pemberi dan penerima pelayanan dengan tetap berpegang pada prinsip efisiensi dan akuntabilitas; 4). Partisipatif, artinya mendorong peran serta masyarakat dalam penyelenggaraan pelayanan publik dengan memperhatikan aspirasi, kebutuhan dan harapan masyarakat; 5). Kesamaan hak, artinya tidak diskriminatif, tidak membedakan suku, ras, agama, golongan, gender, dan status ekonomi; 6). Keseimbangan, artinya hak dan kewajiban pemberi dan penerima pelayanan publik harus memenuhi hak dan kewajiban masing-masing pihak.

Akuntabilitas (accountability) dalam pelayanan publik dimengerti sebagai ukuran yang menunjukan apakah aktivitas birokrasi publik atau pelayanan yang dilakukan oleh pemerintah sudah sesuai dengan norma dan nilai-nilai yang dianut oleh rakyat dan apakah pelayanan publik tersebut mampu mengakomodasi kebutuhan rakyat yang sesungguhnya dan akuntabilitas adalah suatu derajat yang menunjukkan besarnya tanggung jawab aparat atas kebijakan maupun proses pelayanan publik yang dilaksanakan oleh birokrasi pemerintahan (Kumorotomo, dalam Hendry, 2013 http://w4nm4p.blogspot.co.id/, diunduh tanggal 19 Oktober 2020).

Pengadaan barang/jasa yang dikecualikan pada pengadaan barang/jasa Pemerintah, menurut Perpres 16/2018, Pasal 61, ayat 1.c, antara lain: “c. Pengadaan Barang/Jasa yang dilaksanakan sesuai dengan praktik bisnis yang sudah mapan. Sedangkan menurut Peraturan Lembaga Kebijakan Pengadaan Barang/Jasa Nomor 12 tahun 2018: “ Pengadaan barang/jasa yang dikecualikan pada pengadaan barang/jasa Pemerintah adalah pengadaan barang/jasa yang ketentuannya dikecualikan baik sebagian atau seluruhnya dari ketentuan Pengadaan Barang/Jasa Pemerintah sebagaimana diatur dalam Peraturan Presiden Nomor 16 Tahun 2018 tentang Pengadaan Barang/Jasa Pemerintah (Pasal 1, ayat 2). Pengadaan Barang/Jasa yang dilaksanakan sesuai dengan praktik bisnis yang sudah mapan, antara lain: "Barang/jasa yang merupakan karya seni dan budaya dan/atau industri kreatif (Peraturan Lembaga Kebijakan Pengadaan Barang/Jasa Nomor 12 tahun 2018, Lampiran I). Barang/Jasa yang merupakan karya seni dan budaya dan/atau industri kreatif, antara lain: jasa pekerja seni dan budaya (Peraturan Lembaga Kebijakan Pengadaan Barang/Jasa Nomor 12 Tahun 2018, Lampiran I)

Dari uraian tersebut terlihat bahwa Gamelan, yang merupakan karya seni dan budaya, pengadaannya dapat dilaksanakan sesuai dengan praktik bisnis yang sudah mapan, yang menurut Perpres omor 16 Tahun 2018, Pasal 61, ayat 1, dimasukkan ke dalam "pengadaan barang/jasa yang dikecualikan”. Dengan kata lain, pengadaan gamelan dapat dilakukan dengan metode "yang dikecualikan" pada pengadaan barang/jasa Pemerintah.

Koppel menjelaskan bahwa akuntabilitas dalam pelayanan publik, termasuk pengadaan gamelan, memiliki lima dimensi (Maani, 2009:47-48, dalam http://ejournal.unp.ac.id/index.php/jd/article/view/1190/1025, diunduh pada tanggal 12 
Oktober 2020), yaitu: dimensi transparansi, pertanggungjawaban, pengendalian, tanggung jawab, dan responsivitas.

1) Dimensi Transparansi merujuk pada kemudahan akses untuk mendapat informasi terkait dengan fungsi dan kinerja dari organisasi.

Dari penelitian, peneliti menemukan bahwa pengadaan gamelan dengan metode tender yang dikecualikan ini telah dilakukan secara transparan di tiap tahapannya, yaitu tahap perencanaan, persiapan pengadaan, persiapan dan pelaksanaan pemilihan penyedia, dan tahap pelaksanaan kontrak. Langkah-langkah konkret yang diambil untuk mewujudkan dimensi transparansi dalam pengadaan gamelan dengan metode tender yang dikecualikan sebagai berikut: a). Membuat kajian tentang proses dan bahan pembuatan gamelan yang baik dan benar, bersama ISI; b). melakukan pembicaraan yang panjang dengan LKPP Inspektorat untuk melakukan perlem ini; c). Mempermudah proses administrasi bagi para pengrajin (KTP dan NPWP); d). Mengundang para pengrajin untuk mempresentasikan proposal di depan Tim Teknis dan yang dinilai adalah kesanggupan/ kemampuan untuk penyediaan gamelan sesuai standar yang ditentukan.

2) Dimensi Pertanggungjawaban merujuk pada praktik untuk memastikan individu dan atau organisasi bertanggung jawab atas tindakan dan aktivitasnya, memberikan hukuman pada tindakan yang salah dan memberikan penghargaan atas kinerja yang baik.

Dari penelitian, peneliti menemukan bahwa pengadaan gamelan dengan metode tender yang dikecualikan secara langsung ke pengrajin dan tidak melalui penyedia jasa. Alasannya, metode tender yang dikecualikan ini dipilih karena Gubernur DIY menghendaki adanya percepatan dan perluasan dalam pengadaan Gamelan. Gubernur menghendaki agar semua kecamatan, kelurahan dan Desa Budaya, termasuk semua sekolah di DIY segera memiliki Gamelan (https://www.harianmerapi.com, diakses tanggal 9 November 2020). Pertimbangan lain dengan penggunaan metode ini ialah fakta bahwa gamelan tidak hanya mengandung unsur wujud barang yang bernilai seni saja tetapi mempunai makna filosofis. Nah nilai seni dan filosofis ini umumnya lebih dimengerti oleh pengrajin daripada perantara atau penjual Gamelan. Oleh karena itu Kundha Kabudayan ingin langsung berhubungan dengan pengrajin dengan metode tender yang dikecualikan.

Selain itu, pengadaan gamelan dilaksanakan berdasarkan Peraturan Presiden Nomor 16 Tahun 2018 Peraturan Kepala LKPP Nomor 12 Tahun 2018 tentang Pengadaan barang/jasa yang dikecualikan. Dari informasi yang peneliti peroleh di lapangan, Reward dan punishmen kepada pokja selama ini belum pernah diberikan, sebab semua telah dilaksanakan sesuai perundangan yang berlaku dan disadari oleh Pokja bahwa pengadaan gamelan ini sudah menjadi tugas dan tanggung jawab pokja.

3) Dimensi Pengendalian, merujuk pada situasi bahwa organisasi melakukan secara tepat apa yang menjadi perintah utamanya.

Dari penelitian, peneliti menemukan bahwa pengadaan gamelan dengan metode tender yang dikecualikan, dikendalikan dengan SOP yang dibuat oleh LKPP dan Tim Teknis dari ISI berdasarkan Perpres No 16 Tahun 2018, Peraturan LKPP Nomor 12 Tahun 2018, serta Tata Cara Pengadaan Gamelan dari Direktorat Advokasi Penyelesaian Sanggah Wilayah II LKPP.

Bagian Layanan Pengadaan Biro Pengembangan Infrastruktur dan Pembiayaan Pembangunan Sekretariat Daerah DIY, ikut mengontrol atau mengendalikan dalam arti yang luas. Artinya ikut mengontrol kemajuan para pengrajin dan penyedia jasa, agar mereka dapat tumbuh dan berkembang bersama, dalam sebuah persaingan yang semakin sengit dan luas. Pelaksanaan tender yang dikecualikan ini adalah suatu proses 
tender yang baru dicoba di DIY, maka sudah barang tentu dapat menimbulkan friksi di kalangan penyedia jasa (bukan pengrajin). Hal ini malah sebagai kesempatan kepada Kundha Kabudayan DIY untuk merangkul mereka para penyedia jasa/leveransir.

4) Dimensi Tanggung jawab, merujuk pada organisasi hendaknya dibatasi oleh aturan hukum yang berlaku.

Dari penelitian, peneliti menemukan bahwa pengadaan gamelan dengan metode tender yang dikecualikan dijamin dengan adanya standart kompetensi yang dipersyaratkan dalam proses pengadaan Gamelan bagi para Tenaga Teknis dan Pokja BLP.

Peran Tim Teknis sangat besar karena Tim ini bertugas mendata, menilai dan menyeleksi proposal yang masuk dan di akhir kegiatan memunculkan satu nama perusahaan yang layak untuk mengerjakan paket pengadaan gamelan tersebut.

Adapun untuk dimensi tanggungjawab dari sisi Kelompok Kerja Pengadaan Barang di Biro PIWPP telah diatur mekanismenya sesuai dengan aturan yang telah ada. Dari observasi di lapangan, peneliti mengetahui bahwa personil yang telah ditunjuk menjadi Kelompok kerja adalah pegawai Pemerintah Daerah DIY yang telah lulus dan mempunyai Sertifikat Pengadaan Barang/Jasa Pemerintah yang dikeluarkan oleh LKPP.

5) Dimensi Responsivitas merujuk pada organisasi menaruh minat dan berupaya untuk memenuhi harapan substantif para pemangku kepentingan yang bentuknya berupa artikulasi permintaan dan kebutuhan. Wujud responsibilitas dari Kundha Kabudayan sebagai berikut: Dalam pelaksanaan RPJMD khususnya bidang Kebudayaan yang diampu oleh Kundha Kabudayan, hampir setiap tahun Bidang Perencanaan Kundha Kabudayan selalu memasukkan program Pengadaan Gamelan baik itu Gamelan baik berbahan Perunggu, besi maupun kuningan. Pengadaan Gamelan yang ditenderkan tiap tahun selalu ada, sehingga selalu berkoordinasi dengan Biro Pengembangan Wilayah dan Pembiayaan Pembangunan Setda DIY dalam hal ini Bagian Layanan Pengadaan

Dari penelitian, peneliti menemukan bahwa pengadaan gamelan dengan metode tender yang dikecualikan, merupakan respon animo masyarakat, pengrajin, Desa Budaya, Kelompok Seni dan Gubernur DIY untuk memperkuat keistimewaan DIY. Setiap tahun Bidang Perencanaan Kundha Kabudayan memprogramkan dan menenderkan pengadaan Gamelan. PPK selalu berkoordinasi dengan BLP.

Dari observasi di lapangan peneliti mengetahui bahwa respon para pengrajin gamelan di DIY dan sekitarnya dengan dilakukannya proses tender yang dikecualikan ini sungguh sangat posisif. Sebab para pengrajin yang selama ini hanya diajak kerjasama oleh para penyedia jasa atau leveransir yang secara adminsitrasi memenuhi persyaratan tender tapi tidak mempunyai kekuatan dari sisi teknis, maka dengan metode yang dikecualikan ini, pengrajin yang akan langsung berkontrak dengan PPK. Sehingga secara ekonomis, para pengrajin akan dapat mengelola keuangannya sendiri, dengan disesuaikan bahan gamelan yang dibutuhkan dan kebutuhan belanja lainnya tanpa ada ketakutan akan terbatasnya dana. Selama ini pengrajin yang bersedia membantu para penyedia jasa hanya mendapatkan jatah yang terbatas dari para penyedia jasa, sehingga dana tersebut sudah barang tentu disesuaikan dengan kualitas bahan dan pembuatan gamelan. Akibatnya gamelan yang dibuat pengrajin jauh dari kaidah gamelan yang berkualitas. 


\section{Kendala-Kendala yang Dihadapi dalam Pengadaan Gamelan dengan Metode Tender yang Dikecualikan.}

Kendala-kendala yang dihadapi dalam pengadaan gamelan dengan metode yang dikecualikan juga dilihat dari dimensi akuntabilitas, dan hasil penelitian ini sebagai berikut: Kendala dari dimensi transparansi dalam pengadaan gamelan dengan metode tender yang dikecualikan ini tidak ada yang berarti, karena pengrajin dibantu oleh anak/saudara yang menguasai IT untuk mengakses informasi dan mengikuti proses. Kendala kecil datang dari penyedia jasa yang tak lagi digunakan karena Kundha Kabudayan langsung berhubungan dengan pengrajin gamelan.

Kendala dari dimensi pertanggungjawaban dalam pengadaan gamelan dengan metode tender yang dikecualikan tidak ada. Selama ini pelaku-pelaku pengadaan di Kundha Kabudayan belum pernah menerima punishment dan juga tidak pernah menerima reward. Kendala dari dimensi pengendalian dalam pengadaan gamelan dengan metode tender yang dikecualikan ini terletak dari belum adanya standar penentuan tenaga ahli. Karena pengendalinya adalah kepercayaan antara pelaku pengadaan dan pengrajin, seringkali kendalanya terletak dalam memacu penyelesaian sesuai target waktu. Kendala dari dimensi tanggung jawab dalam pengadaan gamelan dengan metode tender yang dikecualikan, tidak ada yang berarti, karena pengadaan gamelan dilaksanakan berdasarkan Perpres dan aturan lainnya, yang mengatur tender yang dikecualikan ini. Pemilihan pengrajin melalui Tim Teknis dan yang terpilih diproses oleh Pokja BLP. Sudah ada kesepahaman dalam mempermudah syarat dan pencairan dana dengan pihak Inspektorat. Kendala dari dimensi responsivitas dalam pengadaan gamelan dengan metode tender yang dikecualikan ada dalam pengadaan gamelan perunggu yang tak sebanding dengan banyaknya kebutuhan gamelan perunggu di DIY; sedangkan gamelan besi sudah dapat dipenuhi oleh pengrajin dari DIY.

\section{KESIMPULAN DAN SARAN}

Dari seluruh uraian yang telah disampaikan, peneliti membuat simpulan: Pengadaan gamelan dengan metode tender yang dikecualikan di Kundha Kabudayan DIY sudah dilaksanakan secara akuntabel. Alasannya: 1). pengadaan gamelan dengan metode tender yang dikecualikan ini telah dilakukan secara transparan di semua tahapannya, yaitu: tahap perencanaan, persiapan pengadaan, persiapan dan pelaksanaan pemilihan penyedia, dan tahap pelaksanaan kontrak; 2). pengadaan gamelan dengan metode tender yang dikecualikan, telah dilaksanakan berdasarkan perpres dan peraturan yang berlaku, dan hasilnya lebih baik; 3). dikendalikan dengan SOP yang dibuat oleh LKPP dan Tim Teknis dari ISI berdasarkan Perpres dan peraturan yang berlaku; 4). Para Tenaga Teknis dan Pokja BLP dijamin kompetensinya dengan standart kompetensi yang dipersyaratkan dalam proses pengadaan Gamelan bagi; 5). Pengadaan gamelan dengan metode tender yang dikecualikan, merupakan respon atas animo masyarakat luas dan pengadaannya diprogramkan dan ditenderkan tiap tahun di Kundha Kabudayan. Kendala-kendala yang dihadapi adalah 1). belum adanya standar penentuan tenaga ahli dalam Tim Teknis; 2). kesulitan memacu pengrajin untuk menyelesaikan sesuai target waktu; dan 3). kekurangan pengrajin gamelan perunggu di wilayah DIY.

Berdasarkan simpulan itu, peneliti mengajukan saran-saran: Agar informasi dan undangan tender disebar-luaskan secara transparan dan merata kepada pengrajin dan penyedia jasa., agar terjadi persaingan yang sehat antara penyedia jasa dan pengrajin demi peningkatan kualitas gamelan dan penghematan anggaran. Agar di awal termint diadakan sosialisasi peraturan tentang pengadaan gamelan dan SOP dalam memenuhi target, supaya pengrajin semakin melek hukum dan melek informasi. Agar segera dibuat standar penentuan tenaga ahli, agar kualitas dan kontinuitas Tim Ahli/Tim Teknis semakin dapat diandalkan, karena dalam tender yang dikecualikan ini, Tim Teknis sangat diandalkan. Awal dan akhir termint pembayaran, pengrajin terus didampingi dan dimotivasi agar mereka semakin dapat dipercaya, karena kepercayaan 
merupakan landasan utama pengadaan gamelan dengan tender yang dikecualikan. Kundha Kabudayan memacu pertumbuhan pengrajin perunggu di DIY, dengan mengadakan pelatihan secara rutin dan kompetisi tiap tahun sekali.

\section{DAFTAR PUSTAKA}

Badzlina Daroyani Novitaningrum. 2014. "Akuntabilitas dan Transparansi Pengadaan Barang dan Jasa Pemerintah Melalui Electronic Procurement" (Best Practice di Pemerintah Kota Surabaya), Program Studi Ilmu Administrasi Negara, FISIP, Universitas Airlangga, Surabaya, dalam Jurnal Kebijakan dan Manajemen Publik, Volume 2, Nomor 1, Januari.

Prastowo, Andi. 2016. Metode Penelitian Kualitatif dalam Perspektif Rancangan Penelitian. Ar Ruzz Media. Jogjakarta.

Qori Lusi Pratiwi, Choirul Saleh, Abdul Wahid. 2014. "Akuntabilitas dalam Pengadaan Barang dan Jasa Pemerintah Melalui Sistem E-Procurement" (Studi pada Layanan Pengadaan Secara Elektronik Pemerintah Kabupaten Kediri), Jurusan Administrasi Publik. Fakultas Ilmu Administrasi, Universitas Brawijaya, Malang, dalam Jurnal Adiministrasi Publik (JAP), Vol. 2, No. 2, Hal 344-349.

Sugiyono, 2010, Metode Penelitian Kunatitatif Kualitatif dan R\&D. Bandung Alfabeta.

Yanuar Siswo Nugroho dan Zulkifli. 2019. “Akuntabilitas Publik Pengadaan Barang/Jasa Pemerintah Secara Elektronik (E-Procurement) di Pemerintah Daerah Daerah Istimewa Yogyakarta, Magister Manajemen STIE Widya Wiwaha, Yogyakarta, dalam Jurnal Riset Manajemen, Vol. 6, No. 2, Juli, 173-184.

Yusuf, A.M. 2014 Metode Penelitian Kuantitatif, Kualitatif, dan Penelitian Gabungan. Kencana. Jakarta

AhmadIbo, Gamelan, Kesenian Adiluhung dari Jawa, https://www.indonesiakaya.com/jelajahindonesia/detail/gamelan-kesenian-adiluhung-dari-jawa, diunduh tanggal 26 Oktober 2020

Maani, Karjuni Dt. 2009. Transparansi dan Akuntabilitas dalam Pelayananan Publik, DEMOKRASI Vol. VIII No. 1 dalam http://ejournal.unp.ac.id/ index.php/ jd/article/view/1190/1025), diunduh pada tanggal 12 Oktober 2020

Pemerintah Daerah Daerah Istimewa Yogyakarta. 2018. Visi-Misi Pemda DIY 2017-2022 Fokuskan SDM dan Tata Kelola Pemerintahan, https://jogjaprov.go.id/berita/detail/visimisi-pemda-diy-2017-2022-fokuskan-sdm-dan-tata-kelola-pemerintahan, diunduh tanggal 28 Oktober 2020

https://www.harianmerapi.com/news/gunung-kidul/2018/12/08/44960/dari-anggaran-danais47-desa-di-gunungkidul-terima-bantuan-gamelan, diakses tanggal 9 November 2020

https://jogjaprov.go.id/ berita/detail/visi-misi-pemda-diy-2017-2022-fokuskan-sdm-dan-tatakelola-pemerintahan, diunduh tanggal 28 Oktober 2020

Undang-undang Nomor 25 Tahun 2009 tentang Pelayanan Publik

Undang-undang Nomor 13 Tahun 2012 tentang Keistimewaan DIY

Peraturan Presiden Republik Indonesia Nomor 16 Tahun 2018 tentang Pengadaan Barang/Jasa Pemerintah

Keputusan Menteri Pendayagunaan Aparatur Negara Nomor 63 Tahun 2003 tentang Pedoman Umum Penyelenggaraan Pelayanan. Publik 
Pengadaan Gamelan yang Akuntabel dengan Metode Tender Dikecualikan di Dinas Kebudayaandaerah Istimewa Yogyakarta, - Sumitro Yuwono, Tri Nugroho

Peraturan Lembaga Kebijakan Pengadaan Barang/Jasa Pemerintah Nomor 12 Tahun 2018 tentang Pedoman Pengadaan Barang/Jasa yang Dikecualikan pada Pengadaan Barang/Jasa Pemerintah

Peraturan Gubernur Nomor 72 Tahun 2008 tentang Budaya Pemerintahan di Daerah Istimewa Yogyakarta. 